\title{
Why 108 Times Mala Japa is prescribed in Hinduism?
}

\section{Opinion}

A group of people visited a temple and circumambulated it for 108 times. Then, they approached a temple priest. He gave them a 108 beads chaplet and recommended them to chant it daily for 108 times for attaining the blessings of happiness, peace, prosperity and spirituality. Why for 108 times...?

The number 108 is divisible of 9 . Not only number 108 but also those numbers which fall in table 9 are considered auspicious in Hinduism. Yes, of course, the number 108 has a prominent place. The summation of the digits of the numbers of table 9 always remains 9. E.g. $9 * 7=63$ (6 3=9), 9*5=45 (4 5=9) , 9*16=144 (1 4 $4=9)$ etc. This reinforces that the number 9 has a significant place in the Metaphysics. Let us dig deeper.

According to Ayurveda, there are 108 pressure points in the body, where consciousness and flesh intersect to give life to the living being. A healthy heart pulsates 72 (7 2=9) times in a minute. 108 degrees Fahrenheit is the internal temperature at which the human body's vital organs begin to fail from overheating. Therefore, the number 108 is considered good for mind and destiny (astrology). In the astrology, there are the 9 planets and 12 houses. The multiplication of $12 * 9$ is 108 (1 0 8=9). There are 27 (2 7=9) Nakshatra. These Nakshatra are the wives of Chandra, the moon. The moon is considered the deity of the mind in the astrology. The silver metal is associated with the moon, which has atomic weight 108 (107.8682).

The human fetus lives in the mother`s womb for 9 months $(36$ weeks). This specific time period ( 9 months) of the fetus in the mother`s womb is given by nature to the human being only, not to any other creatures. The body, in which we live, has 9 doors (eyes, ears, nose, mouth, anus and genital).

The biggest epic, the Mahabharata contains 18 chapters, the Mahabharata war lasts for 18 days. There were total 18 armies in this battle - 11 from Kauravas and 7 from Pandavas. The Bhagawat Gita emerged in the midst of the battlefield of Kurukshetra for the welfare of the whole humanity contains 18 chapters. Pandu had the family of 9 members (Pandu, Kunti, Madri and 4 children from Kunti including Karna, and 2 from Madri).

Yudhishthira gambled away everything in 18th game. Jarasandha triumphed Mathura, the city of Lord Krishna, in the 18th attack. Bhishma was invincible in the battlefield for 9 days. No one had prowess and brawn to overthrow Bhishma except Krishna, who had taken the oath of not lifting the weapons against anyone in the war. At the end of 9th day, Bhishma revealed the secret of his death to Pandavas, and on the 10th day, he was killed deceivably. Pandavas ruled over Hastinapura for 36 (3 6=9) years after the Mahabharata war. The number of kings of snakes has mentioned is 9, the Nag. One of the kings of snakes, Takakshat, bites Prikshit, the grandson of Arjun to death.

In Hinduism, there are 18 Puranas and 108 Upanishads

Opinion
Volume 10 Issue 2 - 2017
Sarvottam Kumar*
Shree Mahesh Heritage, India
*Corresponding author: Sarvottam Kumar, Shree Mahesh
Heritage, Kunjapuri C/0-Hotel Khushal Palace, Upper
Tapovan, Vill-Guagtyani Malli, Tapovan, Rishikesh, India, Tel:
9760061076; Email: shreemaheshheritage@gmail.com
Received: December 27, 2016 | Published: December 27,
2017

(Maybe more, but principally considered 108), S. Radhakrishnan, considers 18 principal Upanishads. The shape of the earth is an oblate spheroid, which makes 360 (3 6 0=9) degree. Vishnu and Lord Shiva have 1008 names. Sanskrit is the classical language of Indians and the liturgical language of Hinduism, Buddhism, and Jainism. It is also one of the 22 official languages of India, contains 54 (5 4=9) alphabets.

The Sri Yantra is very auspicious in Hinduism, and it is considered the harbinger of both prosperity and spirituality. Each triangle has 180 degrees. The Sri Yantra is made with the interjection of 4 upward and downward triangles. Total 9 triangles. The upward triangle is for Purusha(Shiva), the male, and the downward is for Prakriti (Shakti), the female. Hence, the Sri Yantra is a combination of Shiva (Spirituality) and Shakti (Prosperity).

There are 54 intersections in it, where three lines intersect. Each intersection has masculine (Shiva) and feminine (Shakti) qualities. 54 times 2 equal 108. Thus, there are 108 points that define the Sri Yantra as well as the human body. Hence, the number 108 is best suited for the body as well as prosperity. The age of adulthood, casting a vote and applying for a job is decided by the government of India is 18 (1 8=9) years. The RamNavmi and Nav Durga festivals last for 9 days. There are 10 incarnations of lord Vishnu. 9 incarnations are completed. The 10th incarnation, the Kalki avatar, is for the destruction.

The Sikh tradition has a mala of 108 knots tied in a string of wool, rather than beads. The Chinese Buddhists and Taoists use a 108 bead mala. Chinese astrology says that there are 108 sacred stars. Some ring a bell 108 times to celebrate a new year. The first manned space flight lasted in the space for 108 minutes on April 12, 1961 (by Yuri Gagarin, a Soviet cosmonaut). All the above numbers are called the Harshad number, "the great joy", which is an integer divisible by the sum of its digits. The individual numbers 1, 0, and 8 represent one thing, nothing, and everything (infinity). We have observed from above description that 9 is an eternal indestructible number, which resembles the characteristics of the spirit. 
Bhagavad Gita (2.17) says - "That which pervades the entire body, know it to be indestructible. No one can cause the destruction of the imperishable spirit." Hence, number 9 and its multitudes are considered the best-suited numbers for the spirituality, the knowledge of the spirit. And the person who knows the self, there is nothing in this world for him to be known. The number 108 or the multiples of 9 represents the indestructible supply of health, wealth, destiny, love, career, happiness and spirituality. It is very logical to consider it a sacred number in Hinduism.

\section{Acknowledgement}

None.

\section{Conflict of Interest}

None. 